same author. A preliminary sheet of central Italy was shown to the Congress of the International Geographical Union at Washington in 1952 and the maps, in full colour, show twenty eategories of landuse following closely the recommended categories laid down by the Commission on the World Land Use Survey. The Survey has since recognized the vital importance of separating irrigated and nonirrigated lands, which has been done on the Italian maps. Anyone familiar with Mediterranean lands will know the intimate mixtures of trees and ground crops-olives with cereals, for example-and will recognize the justification of this mixed category. Little of Sicily is shown as 'sterile' except the higher slopes of Etna.

Though differing widely in their methods and execution, all these maps illustrate the growing recognition that before land can be planned the present position must be surveyed and analysed.

L. DUdLEY STAMP

\title{
AGRICULTURAL RESEARCH IN EIRE
}

\section{AN FORAS TALU'NTAIS (THE AGRICULTURAL INSTITUTE)}

$\mathrm{A}^{\mathrm{N}}$ N Foras Talúntais was established under the Agriculture (An Foras Talúntais) Act, 1958, and commenced activities on August 1, 1958. Its functions include reviewing, facilitating, encouraging, assisting, co-ordinating, promoting and undertaking agrieultural research in the Republic of Ireland. The Institute has authority to provide, where necessary, new facilities and staff to carry out research, to assist in carrying out specific research projects and to make grants for the extension and development of facilities to scientists actively engaged in agricultural research. The Institute is specifically obliged to disseminate the results of agricultural research, particularly to those engaged in agricultural advisory work. As one of its major and general functions the Institute has a statutory obligation to advise the Minister for Agricul. ture on any matter relating to agricultural research or agricultural science on which advice is requested by him. As part of its educational activity in the promotion and encouragement of agricultural research, the Institute may provide and organize courses of study in agricultural research and related subjects, and it may also provide and organize seminars, conferences, lectures and demonstrations on agricultural research ; it may grant scholarships, and award fellowships to persons who have done outstanding work in relation to agricultural science or agricultural research.

The Institute is an autonomous national body, governed by a Council which consists of a chairman and twelve ordinary members. The chairman is appointed by the President of Ireland. Five members of the Council are nominated by agricultural and rural organizations; the nomination is by means of election by a panel of twenty-five organizations divided into five groups ; one member is nominated by each of the governing bodies of the University Colleges of Cork, Dublin and Galway and the Board of Trinity College, Dublin, and the three remaining members are nominated by the Government of the Republic of Ireland. The activities and staff of the Institute are under the control of a director responsible to the Council as chief officer of the Institute. The finances of the Institute are provided for under a number of headings. From the Counterpart Special Account, by arrangement between the United States and the Irish Governments, the Institute has available a capital fund of $£ 840,000$ to be expended on capital projects and an endowment fund of $£ 1,000,000$. A grant towards the expenses of the Institute will be paid every financial year out of monies provided by the Irish Government. The Institute is empowered to accept gifts of money, land or other property under specified conditions which must be consistent with the functions of the Institute. With regard to gifts and fees for specific research projects, the Institute looks for support particularly to industries and businesses closely associated with agriculture and to farming organizations and individuals interested in agricultural development.

The activities of the Institute have been organized on the basis of a headquarters consisting of a secretariat, scientific and agricultural liaison offices and statistical, library and information services, together with five main Research Divisions as follows: (1) Soils, (2) Plant Sciences and Crop Husbandry, (3) Animal Production, (4) Rural Economy and (5) Horticulture and Forestry. The scientific liaison office will make and maintain contact with agricultural research and allied services in other countries, while in addition providing for the scientific development and co-ordination of the research programme at home. The agricultural liaison office will ensure the closest possible contact, co-operation and integration of effort between the Institute, departments of State, the advisory services and the farming community. A specialist advisory service in each facet of agriculture will be provided for advisory officers and others.

The work of the different Divisions is being developed on the following general basis. The Soils Division will carry out research and specialist advisory activities in the spheres of soil physics, soil chemistry and biochemistry, soil microbiology, soil fertility and fertilizer use, plant nutrition and physio$\operatorname{logy}$, soil classification and survey, land reclamation and land use and the manuring, ecology and survey of grassland. A national soil-survey has already commenced. The Plant Sciences and Crop Husbandry Division will be chiefly concerned with improving the yield and quality of a wide variety of agricultural crops, and will accordingly cater for research in plant breeding, plant pathology, crop protection, entomology, plant introduction (including crops for commercial and other special purposes), plant composition, weed control and general aspects of crop husbandry. The Animal Production Division will cover all phases of animal production from grassland management and feeding to product quality. The work will be organized in the following departments : grassland management, animal husbandry, animal nutrition and biochemistry, physiology, breeding and genetics and meat research. The headquarters of this Division will be at the National Research Centre for Animal Production, at Grange, Dunsany, Co. Meath. A research centre for dairying is being established at 
Moore Park, Fermoy, Co. Cork, and a sheep research centre at Creagh, Ballinrobe, Co. Mayo. The Rural Economy Division will include departments of farm management, agricultural economies, agricultural marketing, rural sociology, home economics and agricultural engineering. It will provide a service for the economic evaluation of the research in other divisions and for the general management programme of the Institute's farms. An agricultural machinery testing service is being organized. The horticultural work of the Horticulture and Forestry Division will be carried out at centres dealing with glasshouse and vegetable crops, soft fruits, pomology and bee-keeping. A National Research Centre for Glasshouse and Vegetable Crops has been established at Kinsealy, Malahide, Co. Dublin. In addition, a field experimental station to cater for soft fruits has been set up at Clonroche, Wexford, and an experimental unit for pomology research at Dungarvan, Co. Waterford.

The foundation ceremony of An Foras Taluntais, commencing with religious services, was held in Dublin on May 19. 'The opening of the headquarters' offices of An Foras Talúntais at 33 Merrion Road, Balls. bridge, Dublin, by the President of Ireland, and the unveiling of a commemorative plaque acknowledging Unites States aid in the foundation of the Institute, took place in the afternoon.

The following officers of the Institute have been appointed :

\section{Director :}

Dr. T. Walsh

Dr. T. Walsh graduated in 1937 and was awarded a postgraduate scholarship which he held in the Soil Science Department, University College, Dublin. He took the degrees of M.Agr.Se. in 1938, Ph.D. in 1940 and D.Se. in 1946 on published work. He was elected a member of the Royal Irish Academy in 1954. During 1938-45 he was assistant lecturer in soil science, in University College, Dublin, and during 1945-52, soils advisory officer in the Department of Agriculture. He was senior inspector in charge of soils and grassland research during 1952-58. In August 1958 he was appointed director of the Agricultural Institute. $\mathrm{He}$ has represented the Republic of Ireland at many scientific and agricultural conferences and is national representative on a number of committees of the Organization for European Economic Co-operation and the United Nations Food and Agriculture Organization. $\mathrm{He}$ was responsible for building up research facilities in soils and grassland research in the Department of Agriculture, especially at Johnstown Castle Agricultural College. Dr. Walsh has specialized in pedology, soil fertility, plant nutrition, and more recently in grassland husbandry with particular reference to the soil fertility - animal nutrition aspects of this subject, and has published some seventy scientific papers.

\section{Chief of the Animal Production Division :}

Dr. L. B. O'Moore

Dr. Laurence Butler O'Moore, who has been appointed chief of the Animal Production Division, took the degrees of M.R.C.V.S. at the Veterinary College in 1945, M.Se. at the University of Dublin for a thesis on the "Physiology of Reproduction" in 1946, and Ph.D. at the University in 1950 for a study on "Phosphorus Deficiency in Grazing Cattle". Since 1948 he has been on the staff of the Veterinary Research Laboratory, Department of Agriculture, where he held the post of superintending senior research officer with responsibility for research dealing with biochemistry, vaccine production and ealf diseases. Dr. O'Moore is a well-known authority in the fields of animal biochemistry, physiology and nutrition. His work on nutritional deficiencies and metabolic disturbances in animals at pasture is especially well known, his reputation in this particular sphere being world-wide.

\section{Chief of the Rural Economy Division :}

$$
\text { Mr. J. J. Byrne }
$$

Mr. James J. Byrne, who has been appointed chiof of the Rural Economy Division, was educated ot: St. Kieran's College, Kilkenny, and the National University, and graduated in law, polities and economics in 1940 , being awarded a postgraduate scholarship. He took the M.A. (Economies) degree at the National University in 1941, being awarded a travelling studentship with which he proceeded to the University of Cambridge, where he was awarded the M.Sc. (Economics) degree in 1944, taking the LL.B. (National University of Ireland) in the same year. In 1946, Mr. Bryne became lecturer in economies in the University of Dublin, where he was appointed registrar of the Schools of Agrieulture and Veterinary Medicine in 1955, and secretary of the Management Committee of the Kells Ingram Farm in 1957. During $1948-54$, in addition to his duties in the University of Dublin, he was secretary of the Population Commission, and this work brought him into particularly close touch with the main national social problems. Mr. Byrne takes up his new post with an international reputation in the sphere of research in economics.

\section{BRITISH MAMMALS AND SOME OTHERS}

N appreciable number of important papers were
produced on a variety of subjects during the
conference of the Mammal Society of the British
Isles, which was held at Bristol during April 6-9.
Miss J. Shillito (University of Exeter) described her
findings on the population structure, ecology and
breeding of the common shrew (Sorex araneus) under
wild conditions : her observations showed much
movement of juveniles before their breeding terri-
tories were established, the range covered by the
males being rather greater than that by the females.
The various invertebrates consumed by shrews were also examined and listed. The other insectivore investigated was the water shrew (Neomys fodiens bicolor). P. A. Jewell and A. E. Hawkins (Royal Veterinary College) had shown that the normal diet. of this shrew had an exceedingly low calorific value, so that the great physical activity employed in the search for food was associated with a resting metabolic rate at least as low as that of a mouse fed on the same standard diet. The Earl of Cranbrook pointed out that the saliva of this shrew was prob- 